\title{
Pooled estimate of vitamin $D$ deficiency among pregnant women in India: a systematic review and meta-analysis
}

\author{
Angeline Jeyakumar ${ }^{1,2^{*}}$, Vidhya Shinde ${ }^{1}$ and Reshma Ravindran ${ }^{1}$
}

\begin{abstract}
Background: Vitamin D deficiency among pregnant women is a public health concern globally. In India, individual studies report high prevalence. However, lack of national data masks the true burden. This work determined the pooled prevalence of vitamin D deficiency among pregnant women in India through a systematic review of literature and meta-analysis.

Methods: Three different search engines yielded 15 eligible articles. Study quality was assessed by 10 different criteria and summary of study quality was categorized as per Cochrane standards. Meta-analysis was performed to estimate pooled prevalence of vitamin D deficiency among healthy pregnant women and heterogeneity among selected studies. A sample of $n=4088$ was used to study the pooled prevalence among pregnant women.

Results: The random effects combined estimate was $32.35 \%\left(95 \% \mathrm{Cl},(12.58-117.48)\right.$. High heterogeneity (tau $^{2}=$ $\left.0.39, I^{2}=100 \%\right)$ and high risk of bias was observed among the selected studies. The test for overall effect was observed to be $z=2.54(P=0.01)$.

Conclusion: Pooled estimate $>30 \%$ emphasizes the need for screening through antenatal care services and initiate preventive measures to address the deficiency.
\end{abstract}

Keywords: Vitamin D deficiency, Pregnant women, Systematic review, Meta-analysis

\section{Introduction}

Vitamin D has emerged as a micronutrient of concern due to widespread prevalence of deficiency [1]. Among the different definitions, Endocrine Society defines deficiency of vitamin $\mathrm{D}$ as serum levels of 25hydroxyvitamin D (25[OH]D) below $20 \mathrm{ng} / \mathrm{ml}$ and levels between 20 and $30 \mathrm{ng} / \mathrm{ml}$ as insufficient [2]. The global prevalence of deficiency or insufficiency ranges between $54-100 \%$ and $39-76 \%$, respectively [3]. Mild to severe deficiencies have been reported both in developed as well as third world countries [4]. Among European

\footnotetext{
* Correspondence: angelinejaykumar@gmail.com; angejp@unipune.ac.in ${ }^{1}$ Interdisciplinary School of Health Sciences, Savitribai Phule Pune University, Maharashtra, India

${ }^{2}$ School of Hospitality Management, University of Johannesburg, Johannesburg, South Africa
}

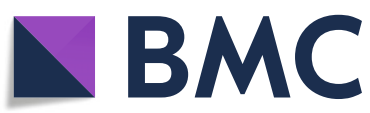

(C) The Author(s). 2021 Open Access This article is licensed under a Creative Commons Attribution 4.0 International License, which permits use, sharing, adaptation, distribution and reproduction in any medium or format, as long as you give appropriate credit to the original author(s) and the source, provide a link to the Creative Commons licence, and indicate if changes were made. The images or other third party material in this article are included in the article's Creative Commons licence, unless indicated otherwise in a credit line to the material. If material is not included in the article's Creative Commons licence and your intended use is not permitted by statutory regulation or exceeds the permitted use, you will need to obtain permission directly from the copyright holder. To view a copy of this licence, visit http://creativecommons.org/licenses/by/4.0/ The Creative Commons Public Domain Dedication waiver (http://creativecommons.org/publicdomain/zero/1.0/) applies to the data made available in this article, unless otherwise stated in a credit line to the data. countries, Belgium reports $>70 \%$ prevalence, while tropical countries in Asia with abundant sunshine report even higher prevalence (> 80\%) [4-6]. Compared to Asia (80\%), African countries show less prevalence (30\%). Among Asian countries, in India, the prevalence of vitamin D deficiency among healthy pregnant women is reportedly high [4, 7]. Individual studies report 93\% prevalence in Delhi, 97\% in Bangalore, Karnataka, and $94 \%$ in Mumbai, Maharashtra [6, 8, 9]. High prevalence has been reported among women in reproductive age group both in rural and urban areas, as well as across economic classes [4].

The physiological role of vitamin D implicated beyond bone health evoked extensive research with this vitamin. From a maternal and child health perspective, its role in 
fertility and conception, pathogenesis in preterm birth, gene transcription in placenta, and immune function are widely researched [10-14]. Deficiency in pregnancy is known to increase risk of pre-eclampsia, gestational diabetes mellitus, preterm birth, and other tissue-specific conditions $[1,11]$. Moreover, vitamin D status of neonates and infants is affected by vitamin $\mathrm{D}$ levels of mothers $[15,16]$. Lactation further increases requirements and severe deficiency has been reported during this phase too [17-20]. As per the guidelines of Endocrine Society, poor vitamin D status in adolescence and increased requirements during pregnancy make the reproductive phase vulnerable $[2,21]$. Unlike other vitamins that are obtained through foods, most of the foods commonly consumed are poor sources of vitamin D. The World Health Organization has emphasized the importance of investigating this vitamin as it affects pregnancy outcome [1]. The paucity of national data and high prevalence as per regional evidence identifies the need to estimate the burden among pregnant women in India. The present work is a systematic review and meta-analysis to determine the combined estimate of vitamin D deficiency among healthy pregnant women in India.

\section{Methods}

Standard protocols for systematic review writing by Khan and coworkers [22] and Preferred Reporting Items for Systematic Reviews and Meta-Analyses (PRISMA) guidelines [23] were followed.

\section{Preliminary research and idea validation}

To ensure validity of the chosen topic and to avoid duplication of work, we performed a preliminary search in PubMed with search terms viz. vitamin D deficiency/insufficiency + pregnant women + India. As we did not come across systematic review and meta-analysis for vitamin $\mathrm{D}$ deficiency among pregnant women or national prevalence data in India, we chose to perform this systematic review and meta-analysis. We also found substantial responses to these search terms that enabled us to progress with this research.

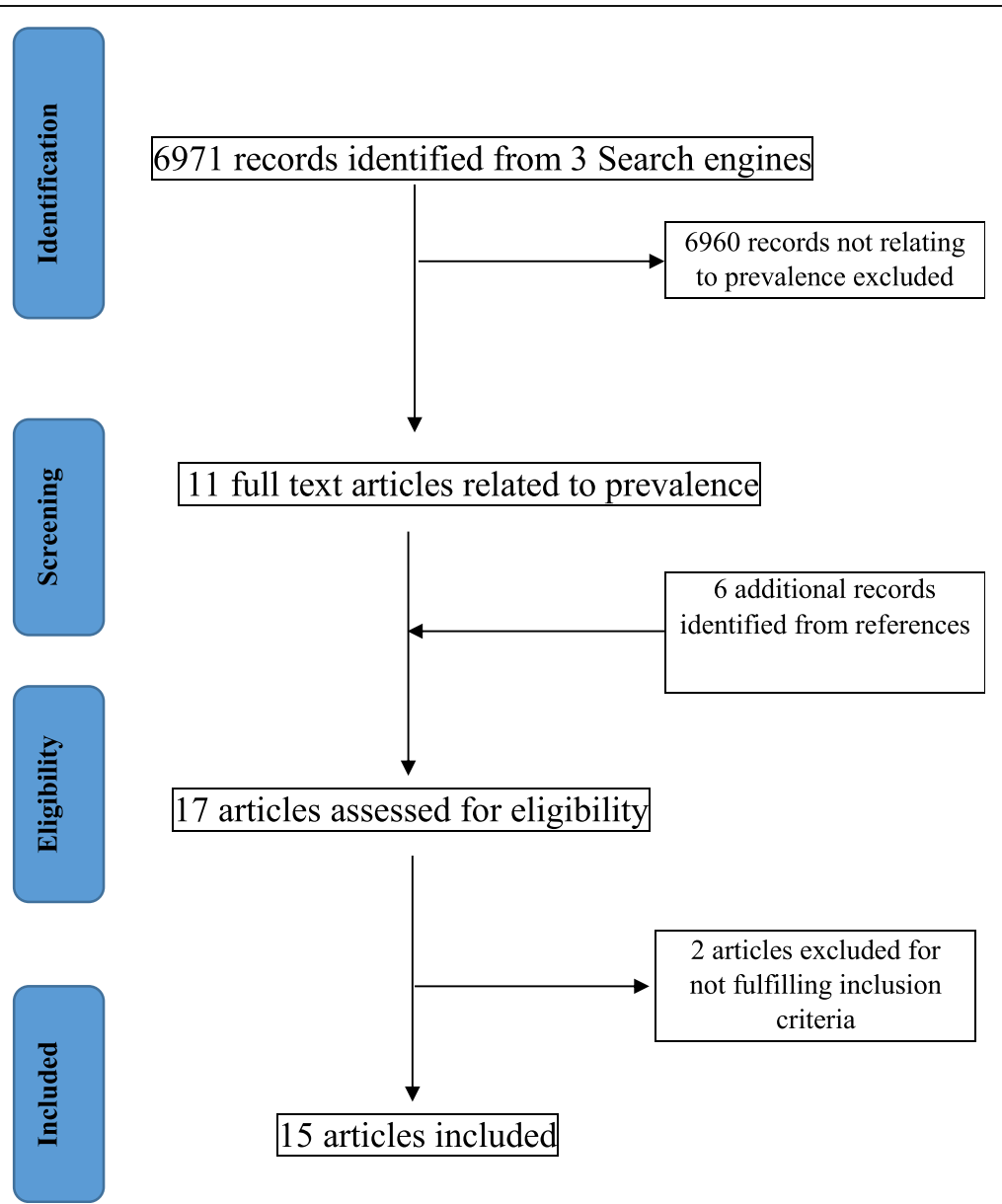

Fig. 1 PRISMA chart: Search strategy and selection of studies 


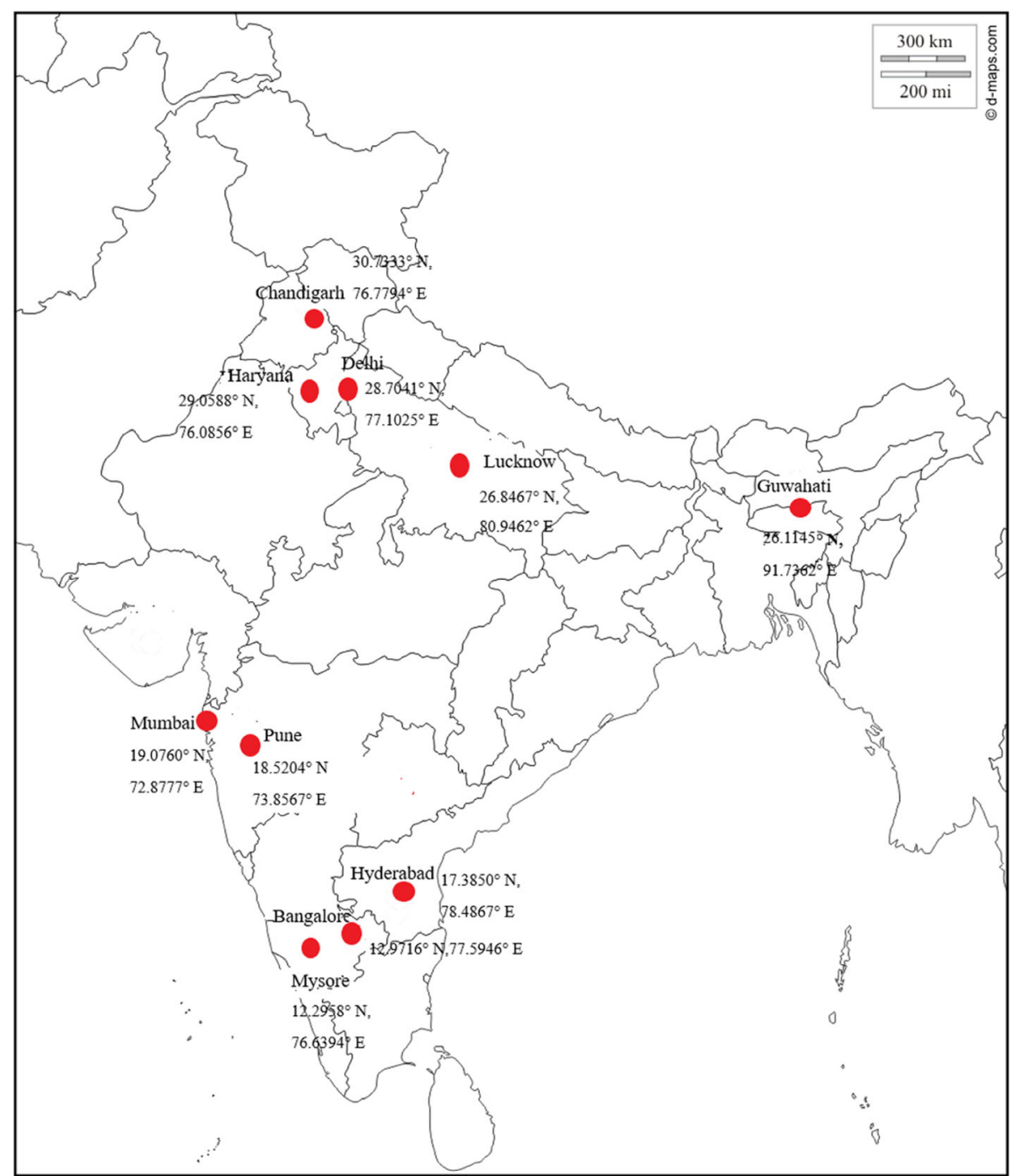

Fig. 2 Map showing studies selected from Indian states and their coordinates

\section{Literature search}

A systematic literature search was performed by two researchers independently in electronic databases that included PubMed, Google Scholar, and Web of Science in November 2018. The search terms used were ("epidemiology"[Subheading] OR "epidemiology"[All Fields] OR "prevalence"[All Fields] OR "prevalence"[MeSH Terms]) AND ("vitamin D deficiency"[MeSH Terms] OR "25 OH Vitamin D levels"[All Fields]) AND ("pregnant women"[MeSH Terms] OR ("pregnant"[All Fields] AND "women"[All Fields]) OR "pregnant women"[All Fields]) AND ("india"[MeSH Terms] OR "india"[All Fields])) AND ("2007/12/03"[PDat] : "2018/11/29"[PDat]) (Fig. 1).

\section{Study selection}

Applying selection criteria (a) studies that were original articles, (b) published in English language, (c) study designs that were observational, intervention studies that provided baseline information on vitamin D levels of healthy pregnant women, (d) India as study location, (e) studies that determined the prevalence of vitamin D deficiency among pregnant women across gestational age, irrespective of parity were selected. (f) Time frame for literature selection was restricted to those published between 2005 and 2018 . (g) As the objective of the present review is to study vitamin D deficiency among pregnant women, studies that recruited pregnant women from hospitals were included. Reference lists of the selected articles were used for manually identifying relevant literature. Fulltext articles that were unavailable and data required for participants in specific age groups were obtained from authors on request. All papers were screened and verified by two researchers independently. 
Table 1 Description of studies among pregnant women in India

\begin{tabular}{|c|c|c|c|}
\hline References & Location & $\begin{array}{l}\text { Sample } \\
\text { size }\end{array}$ & Study design Prevalence \\
\hline Sachan et al. 2005 [31] & $\begin{array}{l}\text { Lucknow } \\
\text { (North) }\end{array}$ & 207 & Cross-sectional $\quad 66.6 \%$ \\
\hline Farrant et al. 2009 [32] & $\begin{array}{l}\text { Mysore } \\
\text { (South ) }\end{array}$ & 559 & Cross-sectional $\quad 66.0 \%$ \\
\hline $\begin{array}{l}\text { Sahu et al. } \\
2009 \text { [33] }\end{array}$ & $\begin{array}{l}\text { Lucknow } \\
\text { (North) }\end{array}$ & 139 & Cross-sectional $\quad 74.0 \%$ \\
\hline Marwaha et al. 2011 [7] & $\begin{array}{l}\text { Delhi } \\
\text { (North) }\end{array}$ & 541 & Cross-sectional $96.30 \%$ \\
\hline $\begin{array}{l}\text { Jani et al. } \\
2014 \text { [9] }\end{array}$ & $\begin{array}{l}\text { Mumbai } \\
\text { (West ) }\end{array}$ & 150 & Cross-sectional $94.0 \%$ \\
\hline $\begin{array}{l}\text { Singla et al. } \\
2015[34]\end{array}$ & $\begin{array}{l}\text { Chandigarh } \\
\text { (North) }\end{array}$ & 304 & Prospective cohort $92.11 \%$ \\
\hline $\begin{array}{l}\text { Ajmani et al. } \\
2016 \text { [35] }\end{array}$ & $\begin{array}{l}\text { Delhi } \\
\text { (North) }\end{array}$ & 200 & Cross-sectional $37.50 \%$ \\
\hline Sharma et al. 2016 [36] & $\begin{array}{l}\text { Delhi } \\
\text { (North) }\end{array}$ & 418 & Prospective cohort $34.54 \%$ \\
\hline $\begin{array}{l}\text { Krishnaveni et } \\
\text { al. } 2011 \text { [37] }\end{array}$ & $\begin{array}{l}\text { Mysore } \\
\text { (South) }\end{array}$ & 568 & Prospective cohort $66.0 \%$ \\
\hline $\begin{array}{l}\text { Veena et al. } \\
20162017 \text { [38] }\end{array}$ & $\begin{array}{l}\text { Mysore } \\
\text { (South) }\end{array}$ & 468 & Prospective cohort $66.8 \%$ \\
\hline $\begin{array}{l}\text { Nandal et al. } \\
2016 \text { [39] }\end{array}$ & $\begin{array}{l}\text { Haryana } \\
\text { (North) }\end{array}$ & 60 & Prospective cohort $93.75 \%$ \\
\hline $\begin{array}{l}\text { Kumar } \\
\text { et al. } 2015 \text { [40] }\end{array}$ & $\begin{array}{l}\text { Bengaluru } \\
\text { (South) }\end{array}$ & 106 & Prospective cohort $70.70 \%$ \\
\hline $\begin{array}{l}\text { Chary et al.2015 } \\
2014 \text { [41] }\end{array}$ & $\begin{array}{l}\text { Hyderabad } \\
\text { (South) }\end{array}$ & 153 & Prospective cohort $52.2 \%$ \\
\hline $\begin{array}{l}\text { Dasgupta } \\
\text { et al. } 2012 \text { [42] }\end{array}$ & $\begin{array}{l}\text { Guwahati } \\
\text { (North-East) }\end{array}$ & 50 & $42.00 \%$ \\
\hline $\begin{array}{l}\text { Sablok et al. } \\
2015 \text { [43] }\end{array}$ & $\begin{array}{l}\text { Delhi } \\
\text { (North) }\end{array}$ & 165 & $77.50 \%$ \\
\hline
\end{tabular}

ELISA enzyme-linked immunosorbent assay, $C I$ confidence interval, $R C T$ randomized control trials

\section{Exclusion criteria}

(i) Earlier work had used > 30 sample as a selection criterion [24]. In our search, the least sample in the eligible studies was $n=20$ and the next higher sample was $n=$ 50. As smaller studies increase the risk of bias, studies with sample size less than 50 were excluded.

(i) Studies that reported vitamin D deficiency associated with specific disease conditions and (ii) eligible studies from which data if unavailable from authors after request were excluded.

\section{Data extraction}

Full texts of the selected articles were retrieved. To avoid publication bias, only peer-reviewed published studies were included. The outcome of interest was combined estimate of vitamin $\mathrm{D}$ deficiency among pregnant women in India. For this, the estimated prevalence of deficiency was recorded from every selected study. In addition, associated variables that describe the study characteristics such as study design, study setting, socio- demographic and economic status, and criteria used to categorize deficiency and sufficiency, season of study, maternal characteristics of pregnant women such as gestational age, and parity were recorded. Data was extracted and entered in Microsoft Excel in duplicate by $\mathrm{RR}$ and VS. Disagreement in selection of articles and data clarification if any was verified by third reviewer AJ.

\section{Assessment of study quality}

Criteria proposed by Hoy and coworkers [25] for prevalence studies were applied to assess the risk of bias in the selected articles. This model applies 10 criteria for assessment of risk of bias. Applying this, the papers were assessed for representation of population, sampling, random selection, non-response bias, data collected directly from subjects, case definition, reliability and validity of the method used, mode of data collection whether similar, length of shortest prevalence period, and numerator and denominator. The summary of study quality was categorized as per Cochrane standards [26] as low (all 
Table 2 Description of associated variables in studies selected for estimating prevalence among pregnant women $(n=15)$

\begin{tabular}{|c|c|c|c|c|c|c|c|c|}
\hline Study & $\begin{array}{l}\text { Age } \\
\text { group/ } \\
\text { mean age }\end{array}$ & Socio-economic status & Education & $\begin{array}{l}\text { Rural/ } \\
\text { urban }\end{array}$ & Parity & Trimester & Exposure to sunlight & $\begin{array}{l}\text { Seasons } \\
\text { of study }\end{array}$ \\
\hline $\begin{array}{l}\text { Ajmani et al. } \\
2016[35]\end{array}$ & $20-25$ & $\begin{array}{l}\text { Lower, upper lower, lower } \\
\text { middle, upper middle }\end{array}$ & $\begin{array}{l}\text { Illiterate, primary } \\
\text { level, graduate }\end{array}$ & Urban & $\begin{array}{l}\text { Multi- } \\
\text { gravida } \\
\text { and } \\
\text { Primigravida }\end{array}$ & All trimesters & NM & NM \\
\hline $\begin{array}{l}\text { Farrant et al. } \\
\text { 2009] [32] }\end{array}$ & $20-26$ & Upper, lower & NM & Urban & NM & $\begin{array}{l}<32 \text { weeks of } \\
\text { pregnancy }\end{array}$ & NM & $\begin{array}{l}\text { Summer, } \\
\text { Winter }\end{array}$ \\
\hline $\begin{array}{l}\text { Jani et al. } \\
2014[9]\end{array}$ & $26.7 \pm 4.1$ & NM & NM & Rural & NM & 2nd trimester & $\begin{array}{l}\text { Summer: } 35.4 \pm 15.9 \text { h/day * } \\
\% \text { BSA }\end{array}$ & $\begin{array}{l}\text { Summer, } \\
\text { Winter }\end{array}$ \\
\hline $\begin{array}{l}\text { Marwaha et al. } \\
2011[7]\end{array}$ & $19-30$ & Lower middle & NM & Urban & $\begin{array}{l}1,2, \text { and }> \\
2\end{array}$ & All trimesters & $\begin{array}{l}\text { 1st trimester: } 10-60 \mathrm{~min} \text { 2nd } \\
\text { trimester: } 10-60 \mathrm{~min} \\
\text { 3rd trimester; } 10-20 \mathrm{~min}\end{array}$ & $\begin{array}{l}\text { Summer, } \\
\text { Winter }\end{array}$ \\
\hline $\begin{array}{l}\text { Sachan et al. } \\
2005 \text { [31] }\end{array}$ & $24 \pm-4.1$ & Lower, middle & NM & $\begin{array}{l}\text { Rural and } \\
\text { urban }\end{array}$ & NM & 3rd trimester & $\begin{array}{l}\text { Urban: } 4.1 \pm 3.2 \mathrm{~h} / \mathrm{day}^{* \%} \% \mathrm{BSA} \\
\text { Rural: } 9.7 \pm 8.1 \mathrm{~h} / \mathrm{day}^{*} \% \mathrm{BSA}\end{array}$ & Autumn \\
\hline $\begin{array}{l}\text { Sahu et al. } \\
2009 \text { [33] }\end{array}$ & $20-25$ & Lower, upper & NM & $\begin{array}{l}\text { Rural and } \\
\text { urban }\end{array}$ & $<3$ & 3rd trimester & Mean $14: 00 \pm 2 \mathrm{~h}$ & $\begin{array}{l}\text { Spring } \\
\text { summer }\end{array}$ \\
\hline $\begin{array}{l}\text { Sharma et al. } \\
2016 \text { [36] }\end{array}$ & $22-23$ & $\begin{array}{l}\text { Lower, upper lower, lower } \\
\text { middle upper middle }\end{array}$ & $\begin{array}{l}\text { Both educated and } \\
\text { not educated }\end{array}$ & Urban & Primigravida & Full term & NM & $\begin{array}{l}\text { Summer, } \\
\text { Winter }\end{array}$ \\
\hline $\begin{array}{l}\text { Singla et al. } \\
2015 \text { [34] }\end{array}$ & $18-35$ & $\begin{array}{l}\text { Upper, upper middle, lower, } \\
\text { lower middle }\end{array}$ & NM & Urban & $\begin{array}{l}\text { Nulliparous, } \\
1 \text { and } 2\end{array}$ & 2nd trimester & $\begin{array}{l}\text { Summer: shorter } \leq 30 \mathrm{~min} \\
\text { Longer > } 30 \mathrm{~min} \\
\text { Winter: } \\
\text { Shorter } \leq 90 \mathrm{~min} \\
\text { Longer }>90 \mathrm{~min}\end{array}$ & $\begin{array}{l}\text { Summer, } \\
\text { Winter }\end{array}$ \\
\hline $\begin{array}{l}\text { Krishnaveni } \\
\text { et al. } 2011 \text { [37] }\end{array}$ & $24 \pm 4.3$ & Lower & NM & NM & NM & 3rd trimester & NM & NM \\
\hline $\begin{array}{l}\text { Veena et al. } \\
2017 \text { [38] }\end{array}$ & $23.9 \pm 4.3$ & Lower & $\begin{array}{l}<10(34.9 \% \\
-10(31.7 \%) \\
>10(33.4 \%\end{array}$ & NM & $\begin{array}{l}1,2, \text { and }> \\
2\end{array}$ & 3rd trimester & NM & NM \\
\hline $\begin{array}{l}\text { Nandal et al. } \\
2016[23,39]\end{array}$ & $\begin{array}{l}30.83 \pm \\
4.0\end{array}$ & upper & NM & urban & NM & 2nd trimester & NM & NM \\
\hline $\begin{array}{l}\text { Kumar et } \\
\text { al. } 2015 \text { [40] }\end{array}$ & NM & NM & NM & NM & NM & NM & NM & NM \\
\hline $\begin{array}{l}\text { Chary et al. } \\
2015 \text { [41] }\end{array}$ & $24.5 \pm 2.6$ & $\begin{array}{l}\text { Upper, upper middle, lower, } \\
\text { lower middle }\end{array}$ & $\begin{array}{l}\text { Illiterate, primary } \\
\text { level, High School } \\
\text { Post high school }\end{array}$ & $\begin{array}{l}\text { Rural and } \\
\text { urban }\end{array}$ & NM & 3rd trimester & $<60 \min$ & NM \\
\hline $\begin{array}{l}\text { Dasgupta et al. } \\
2012 \text { [42] }\end{array}$ & $20-40$ & NM & NM & NM & NM & 1st trimester & $33 \pm 9.07 \%$ & $\begin{array}{l}\text { Summer, } \\
\text { rainy }\end{array}$ \\
\hline $\begin{array}{l}\text { Sablok et al. } \\
2015 \text { [43] }\end{array}$ & NM & Lower, middle & NM & NM & Primigravida & 2nd trimester & $\begin{array}{l}<1 \mathrm{~h} / \text { day } \\
>4 \mathrm{~h} / \text { day }\end{array}$ & NM \\
\hline
\end{tabular}

NM not mentioned

10 criteria assessed to have low risk), moderate (at least two criteria showing high risk), and high risk (more than two criteria showing high risk).

\section{Statistical analysis}

Review manager [27] software version 5.3 was used to obtain a forest plot to demonstrate the degree of heterogeneity among the selected articles. The software uses $\mathrm{Chi}^{2}, \mathrm{I}^{2}$, and $\mathrm{Tau}^{2}$ to study heterogeneity. Estimating pooled prevalence is a testing strategy where prevalence from a number of studies are aggregated into a single sample (or pool), which is then evaluated for the prevalence of interest [28]. In this review, reported prevalence in individual papers was extracted, log transformed, and standard error of proportion of prevalence was estimated. Considering the variation in the selected prevalence studies, and not assuming a uniform effect size in the selected studies, random effects model was used to perform meta-analysis. This model prevents one or few studies influencing the overall estimate and allows more balance in the relative weights of the studies [29]. The P value is the probability from chi-square statistic calculated using estimates of individual study weight, effect size, and overall effect size [30]. Publication bias was assessed using a funnel plot. Asymmetry in the distribution of studies in the funnel plot indicates the extent of bias.

\section{Results}

Literature search using specific search terms on prevalence of vitamin D deficiency among pregnant women in India identified 6971 articles. After screening titles and abstracts for relevance and excluding duplicates, 6960 articles were excluded as they did not match the 
Table 3 Mean levels of serum $25(\mathrm{OH}) \mathrm{D}$ among pregnant women

\begin{tabular}{|c|c|c|c|c|c|}
\hline \multirow[t]{2}{*}{ Study } & \multirow{2}{*}{$\begin{array}{l}\text { Vitamin D } \\
\text { estimation } \\
\text { method }\end{array}$} & \multirow[t]{2}{*}{ Mean serum 25(OH) D } & \multicolumn{3}{|c|}{$25(\mathrm{OH}) \mathrm{D}$ ranges in serum } \\
\hline & & & Deficiency & Insufficiency & Sufficiency/adequacy \\
\hline Ajmani et al. 2016 [35] & ELISA & $23.25 \mathrm{ng} / \mathrm{ml} \pm 18.49$ & $<20 \mathrm{ng} / \mathrm{ml}$ & $20-30$ ng/ml & $>30 \mathrm{ng} / \mathrm{ml}$ \\
\hline Farrant et al. 2009 [32] & Radioimmunoassay & Median: $15.12 \mathrm{ng} / \mathrm{ml}$ & $<20 \mathrm{ng} / \mathrm{ml}$ & NM & NM \\
\hline Jani et al. 2014 [9] & $\begin{array}{l}\text { Chemiluminescent } \\
\text { immunoassay }\end{array}$ & $10.6 \mathrm{ng} / \mathrm{mL}$ & $<20 \mathrm{ng} / \mathrm{ml}$ & $<20-30 \mathrm{ng} / \mathrm{ml}$ & $30 \mathrm{ng} / \mathrm{ml}$ \\
\hline Marwaha et al. 2011 [7] & ELISA & $9.28 \mathrm{ng} / \mathrm{ml}$ & $<20 \mathrm{ng} / \mathrm{ml}$ & NM & NM \\
\hline Sachan et al. 2005 [31] & Radioimmunoassay & $14.93 \mathrm{ng} / \mathrm{mL}$ & $<20 \mathrm{ng} / \mathrm{ml}$ & NM & Normal: $20-80 \mathrm{ng} / \mathrm{ml} \mathrm{nmol} / \mathrm{L}$ \\
\hline Sahu et al. 2009 [33] & Radioimmunoassay & $15.12 \mathrm{ng} / \mathrm{ml} \pm 7.92$ & $<20 \mathrm{ng} / \mathrm{ml}$ & NM & $30 \mathrm{ng} / \mathrm{ml}$ \\
\hline Sharma et al. 2016 [36] & ELISA & Deficiency: $7.10 \pm 1.49 \mathrm{ng} / \mathrm{ml}$ & $\begin{array}{l}\text { Severe } \\
<10 \mathrm{ng} / \mathrm{ml}\end{array}$ & $\begin{array}{l}\text { Deficient } \\
<20 \mathrm{ng} / \mathrm{ml})\end{array}$ & $\begin{array}{l}\text { Normal } \\
32-100 \mathrm{ng} / \mathrm{ml}\end{array}$ \\
\hline Singla et al. 2015 [34] & ELISA & Median: 7.9 ng/ml (IQR 5.7, 12 & $<20 \mathrm{ng} / \mathrm{ml}$ & $<20-30 \mathrm{ng} / \mathrm{ml}$ & $30 \mathrm{ng} / \mathrm{ml}$ \\
\hline Krishnaveni et al. 2011 [37] & Radioimmunoassay & $15.6 \mathrm{ng} / \mathrm{ml}$ & $<20 \mathrm{ng} / \mathrm{ml}$ & NM & NM \\
\hline $\begin{array}{l}\text { Veena et al. } \\
2017 \text { [38] }\end{array}$ & Radioimmunoassay & NM & $<20 \mathrm{ng} / \mathrm{ml}$ & NM & NM \\
\hline Nandal et al. 2016 [39] & ELISA & $11.98 \mathrm{ng} / \mathrm{ml}$ & $<12 \mathrm{ng} / \mathrm{ml}$ & $12-20 \mathrm{ng} / \mathrm{ml}$ & 20-30 ng/ml \\
\hline $\begin{array}{l}\text { Kumar } \\
\text { et al. } 2015 \text { [40] }\end{array}$ & LC-MS/MS & $16.3 \mathrm{ng} / \mathrm{ml}$ & $<20 \mathrm{ng} / \mathrm{mL}$ & NM & NM \\
\hline Chary et al. 2015 [41] & HPLC & NM & $<19 \mathrm{ng} / \mathrm{mL}$ & $20-29 \mathrm{ng} / \mathrm{mL}$ & $>30$ ng/mL \\
\hline Dasgupta et al. 2012 [42] & Radioimmunoassay & $38.4 \pm 18.37 \mathrm{ng} / \mathrm{ml}$ & $<20 \mathrm{ng} / \mathrm{ml}$ & NM & NM \\
\hline Sablok et al. 2015 [43] & ELISA & $18.44 \mathrm{ng} / \mathrm{ml}$ & $<20 \mathrm{ng} / \mathrm{ml}$ & $<20-30 \mathrm{ng} / \mathrm{ml}$ & $30 \mathrm{ng} / \mathrm{ml}$ \\
\hline
\end{tabular}

$N M$ not mentioned, IQR inter quartile range, $S D$ standard deviation

selection criteria. This yielded 11 relevant articles. Six additional records were obtained from references cited within these articles. A total of 17 articles with sample size ranging from 50 to 568 were assessed for eligibility as per the selection criteria that further resulted in exclusion of two articles. Thus, 15 primary studies among pregnant women were included for the review.

Figure 2 shows the states where the studies were carried out and their coordinates on the Indian map. Nine out of 15 studies were conducted in Northern India. Five studies were conducted in south and one study each in west and north-east India. Table 1 describes the articles selected for the review. In all, the sample size in the studies ranged from 50 to 568 . Of the 15 selected studies, 6 were cross sectional and the other 8 were prospective cohorts, and a randomized control trial. All studies were hospital based excluding Sahu's [33] work which was population based with calculated sample size. Table 2 describes the maternal characteristics of selected studies. The age of pregnant women ranged from 18 to 40 years in all the papers reviewed. Socioeconomic status of the study group ranged from upper, middle, and lower income groups. Six out of 15 studies provided information on the educational status of women. Work done by Ajmani and coworkers [35] described the distribution of women as per their level of education. Educational status of participants from other studies ranged from illiterate, primary education to graduates. Study setting was rural, urban, or combined representation of both rural and urban settings.

Parity was described in 7 out of 15 articles [31-44] accordingly pregnant women were primi or multi-gravida, nulliparous, or had parity less than three. Women across trimesters were recruited in two articles [35, 44]. Women in second trimester were enrolled in five studies $[9,32,34,39,43]$ and four studies were conducted during the last trimester of pregnancy [33, 37-40, 42, 43]. Data pertaining to sunlight exposure was provided by 8 out of 15 papers. Of these, two papers $[9,42]$ provided a direct estimation of sunlight exposure by duration to percent body surface area and while two $[9,34]$ provided duration exposed specifically in summer and winter. Ajmani and coworkers [35] worked among burka-clad pregnant women and provided information about sunlight exposure indirectly by the number of hours of outdoor activity and use of sun screens and skin complexion. Eight studies mentioned the seasons of study [9, 32, 34, 36, 42, 44]; however, seven studies did not mention the season of study.

Table 3 describes the techniques used in determining the vitamin D levels and the estimated prevalence in the selected studies. Serum was used as the sample for vitamin D estimation in all the studies. Among the techniques used, ELISA [31, 32, 34, 35, 39, 44] and radioimmunoassay were used in six studies [32-34, 3640, 42, 43] and chemiluminescent assay and HPLC [41] 


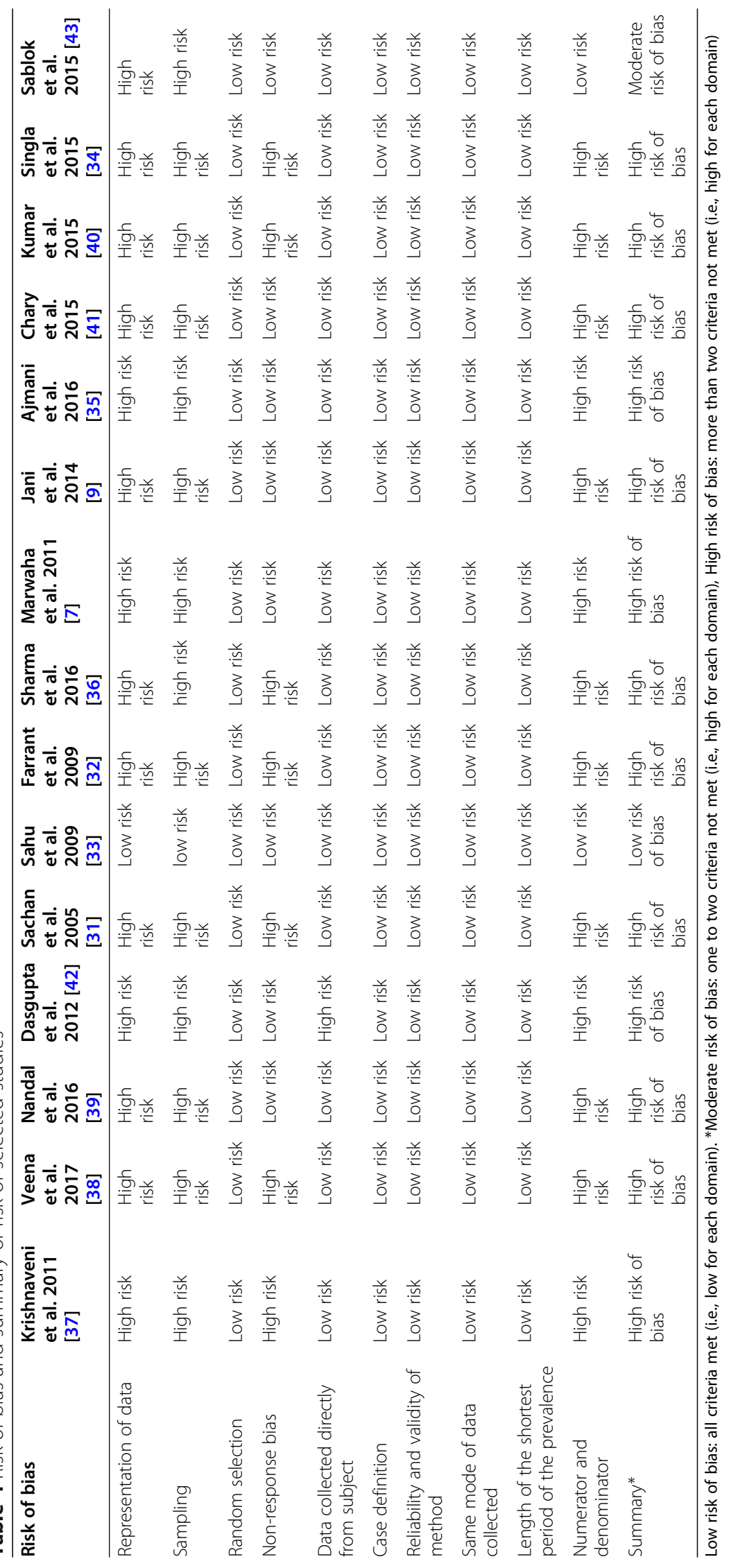




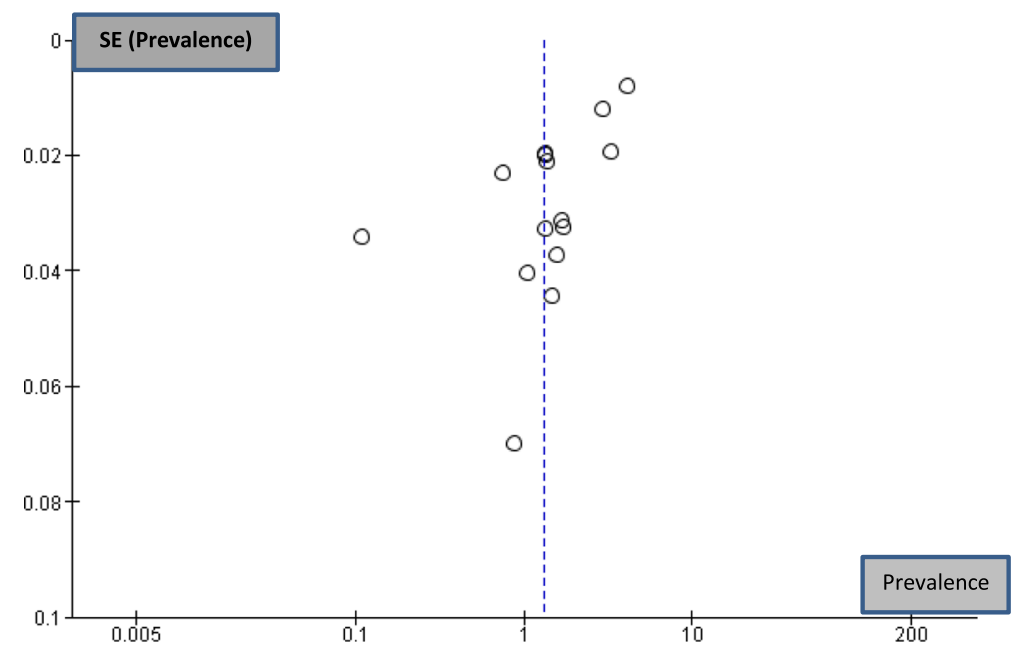

Fig. 3 Funnel plot of individual studies selected for meta-analysis

and LC-MS/MS [40] by one study each. Except Farrant's work [32] (2009), all studies were limited in detail pertaining to standardization and validation of methods. Majority of the studies (13 out of 15)) used $20 \mathrm{ng} / \mathrm{ml}$ as the cuff for defining deficiency, although some studies used [35, 39] 10 or $12 \mathrm{ng} / \mathrm{ml}$ defining severe deficiency. Table 4 summarizes risk of bias (RoB) of the selected papers among pregnant women. Sahu's work [33] was the only population-based study that estimated prevalence based on sample size calculation. Therefore, his work scored low risk in domains pertaining to (i) population representation and (ii) numerator and denominator. All other articles scored high risk in the above-mentioned domains. In all, 13 out of 15 selected studies were categorized as high risk as at least two domains were categorized as high risk, one study each were categorized as moderate and low risk, respectively.

The asymmetrical distribution of studies in the forest plot (Fig. 3) provides a visual representation of publication bias. Figure 4 shows the forest plot derived for the selected studies. The prevalence of vitamin D deficiency among pregnant women ranged from 34.45 to $96.30 \%$. High heterogeneity was observed among the studies $\left(\mathrm{Tau}^{2}=0.39, \mathrm{chi}^{2}=12509.42, \mathrm{df}=14, p=<0.00001, \mathrm{I}^{2}\right.$ $=100 \%)$. The test for overall effect was observed to be $\mathrm{Z}$ $=2.54(p=0.01)$. As per categorization of heterogeneity by Higgins et al. 2003 [45], $\mathrm{I}^{2}>75 \%$ indicates considerable heterogeneity. This indicates large variation among included studies. The random effects combined estimate

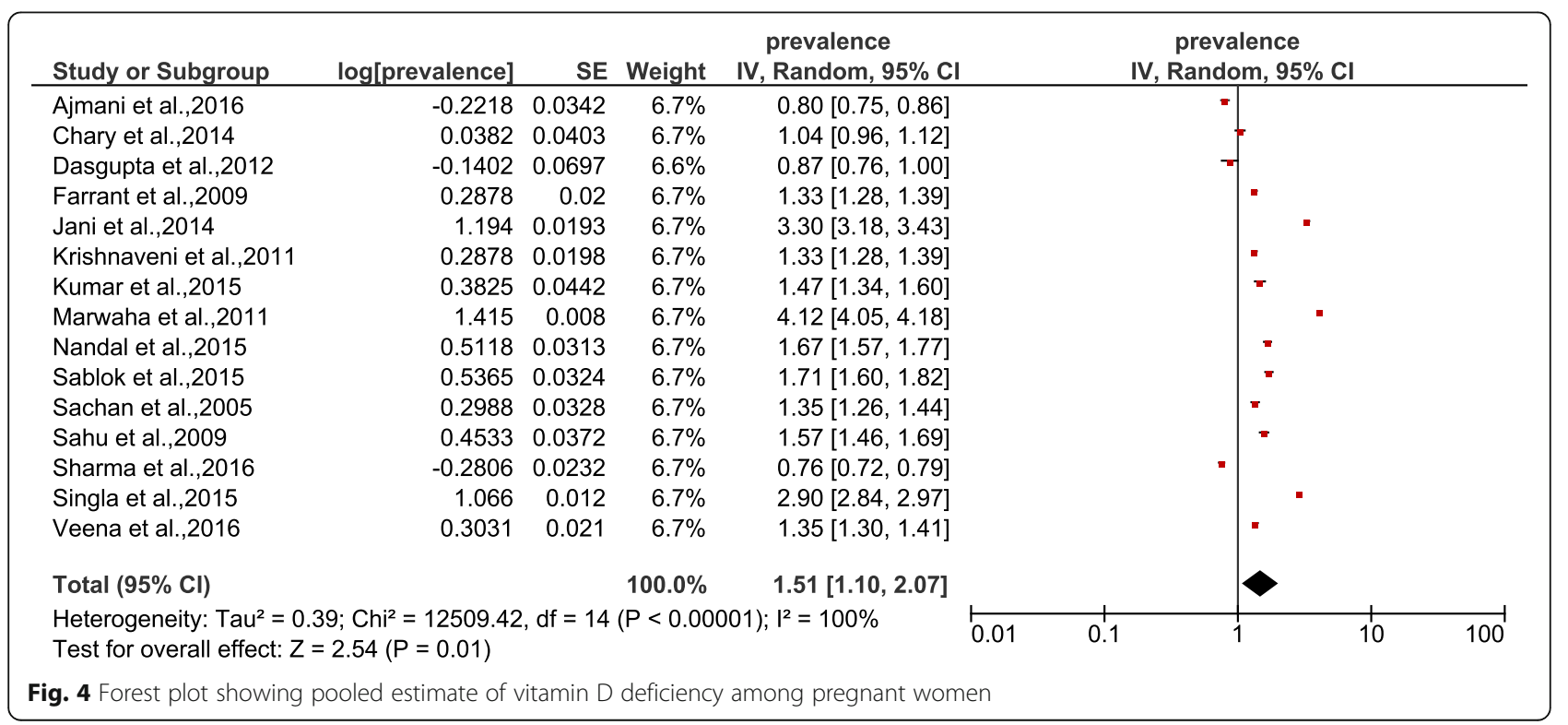


for overall prevalence was $32.35 \%, 95 \%$ CI, $12.58-$ 117.48).

\section{Discussion}

Vitamin D deficiency among women in reproductive age has gained public health attention in recent years. The estimated pooled prevalence as per this review was $32.35 \%$ among healthy pregnant women. As per current literature evidence, a population prevalence $>20 \%$ is considered a public health problem that calls for immediate intervention [46]. Data from individual studies in developing countries report high prevalence in Bangladesh (81\%), Lahore, in Pakistan (73\%), Beijing (40\%), and Malaysia (90\%) [46-49]. Another systematic review among Indian pregnant women by Tasset [50] reported $66-98 \%$ prevalence; however it was not a pooled estimate. These findings underscore the unmet requirements that increase vulnerability during the reproductive phase.

Besides high requirements in pregnancy, geographical location and climate affect vitamin D status. While lack of sunshine contributes to low vitamin D status in developed countries, poor living conditions, economic status, and cultural factors affect those in developing countries despite adequate sunshine. For instance, in Europe and Japan, low and high prevalence were reported in summer and winter, respectively $[51,52]$. Whereas in developing countries, urbanization and transition increase risk for poor vitamin D status irrespective of season [53, 54] Although women in lower socioeconomic strata are highly susceptible, women from higher socioeconomic status who preferred indoors too were at equal risk [55]. Cultural practices such as women covering maximum body surface and veiling prevents maximum sun exposure [56]. Dark skin among south Asians further limits absorption of vitamin D. In resource poor settings houses are closely packed with no direct sunlight within their dwellings and high level of air pollution aggravates vulnerability [57]. High prevalence of deficiency has been reported among migrant women in developing countries [58]. The above factors associated with poor vitamin D status are commonly observed in developing countries as a consequence of urbanization [1, 59-64]. However, rural areas as place of residence did not decrease the risk of vitamin D deficiency. Poor access to nutrient dense foods increased risk in these settings as well [65]. Among maternal characteristics, multi-parity combined with low vitamin $\mathrm{D}$ intake is known to increase risk of deficiency $[16,66,67]$

A global summary of maternal and newborn vitamin D status reports $87 \%$ deficiency among pregnant women in Southeast Asia [68], while pooled estimates show lower prevalence. Varied estimates of prevalence arise due to variations in techniques and difference in defining deficiencies and geographical variations $[69,70]$.

Dearth of national level data in developing countries masks the true burden of this deficiency and limits comparison. National surveys have not focused on screening vitamin D levels of pregnant women for deficiency. In India, the national guidelines recommend $500 \mathrm{mg}$ elemental calcium and $250 \mathrm{IU}$ vitamin D3 twice a day to meet the increased requirements in pregnancy [71]. However, considering the low quality of available evidence between deficiency state and critical pregnancy outcome there exist no recommendation for vitamin D supplementation as part of routine antenatal care [72-74]. This meta-analysis has provided a pooled estimate in the absence of a national prevalence of vitamin $\mathrm{D}$ deficiency. However, it suffers from the following limitations: despite finding eligible studies some studies were excluded due to non-response from authors. Therefore, it is likely that the studies selected for this review are not a representation of the available literature. Although funnel plot was created using RevMan software, statistical test for publication bias could not be performed using this software. Sensitivity analysis could not be performed as prevalence from the excluded papers could not be derived. The high risk of bias due to low power of the selected studies and the time period applied for selecting studies further added to the study limitation.

\section{Conclusion}

The pooled estimate of vitamin D deficiency according to the selected Indian literature identifies a significant percentage of deficiency among pregnant women. Screening of women in reproductive age would identify the magnitude of deficiency to promote early intervention. Vitamin D deficiency is a potentially preventable micronutrient deficiency and high prevalence calls for public health strategies to address this serious issue.

\section{Acknowledgements \\ The authors wish to thank Dr. Sumedha Dharmarajan and Dr. Swapnil Gadhave for their scientific support while we performed the meta-analysis.}

\section{Authors' contributions}

AJ conceptualized the review. VS and RR extracted data and performed the meta-analysis under the guidance of AJ. Manuscript was written by AJ. All authors read and approved the final manuscript.

\section{Funding}

This project was funded by UGC-UPE-2018. The funding body did not play a role in the design of the study, analysis, interpretation of data, and in writing the manuscript.

Availability of data and materials

Please contact author for data requests. 


\section{Declarations}

\section{Ethics approval and consent to participate}

Ethics approval of this study was obtained from the institutional ethics committee Ref: SPPU/IEC/2018/03. Consent was not applicable for this study.

\section{Consent for publication}

All authors have given their consent for this publication.

\section{Competing interests}

The authors declare that they have no competing interests.

Received: 15 September 2019 Accepted: 2 June 2021

\section{Published online: 29 June 2021}

\section{References}

1. World Health Organization. Guideline: vitamin D supplementation in pregnant women.2012; Available in http://www.who.int/nutrition/publica tions/micronutrients/guidelines/vit_d_supp_pregnant_women/en/ Accessed December 2018.

2. Holick MF, Binkley NC, Bischoff-Ferrari HA, Gordon CM, Hanley DA, Heaney $\mathrm{RP}$, et al. Evaluation, treatment, and prevention of vitamin D deficiency: an Endocrine Society clinical practice guideline. J Clin Endocrinol Metab. 2011; 96(7):1911-30. https://doi.org/10.1210/jc.2011-0385.

3. Van der Pligt P, Willcox J, Szymlek-Gay E, Murray E, Worsley A, Daly R. Associations of maternal vitamin $D$ deficiency with pregnancy and neonatal complications in developing countries: a systematic review. Nutrients. 2018; 10(5):640. https://doi.org/10.3390/nu10050640.

4. Edwards MH, Cole ZA, Harvey NC, Cooper C. The global epidemiology of vitamin D status. J Aging Res Clin Prac. 2014;3(3):148-58.

5. Vandevijvere $\mathrm{S}$, Amsalkhir $\mathrm{S}$, Van Oyen $\mathrm{H}$, Moreno-Reyes R. High prevalence of vitamin $\mathrm{D}$ deficiency in pregnant women: a national cross-sectional survey. PloS one. 2012;7(8):e43868. https://doi.org/10.1371/journal.pone.0043 868.

6. Puri S, Marwaha RK, Agarwal N, Tandon N, Agarwal R, Grewal K, et al. Vitamin $D$ status of apparently healthy schoolgirls from two different socioeconomic strata in Delhi: relation to nutrition and lifestyle. $\mathrm{Br} J$ Nutri. 2008;99(4):876-82. https://doi.org/10.1017/S0007114507831758.

7. Marwaha RK, Tandon N, Chopra S, Agarwal N, Garg MK, Sharma B, et al, Vitamin $\mathrm{D}$ status in pregnant Indian women across trimesters and different seasons and its correlation with neonatal serum 25-hydroxyvitamin D levels. Br J Nutri. 2011;106(9):1383-9. https://doi.org/10.1017/S000711451100170X.

8. Divakar H, Singh R, Narayanan P, Divakar GV. Prevalence of Vitamin D Deficiency In A Population Of Indian Women-A Call For Universal Supplementation. J Evid Based Med Healthc. 2017;4(52):3196-200. https:// doi.org/10.18410/jebmh/2017/634.

9. Jani R, Palekar S, Munipally T, Ghugre P, Udipi S. Widespread 25hydroxyvitamin $\mathrm{D}$ deficiency in affluent and nonaffluent pregnant Indian women. BioMed Res Int. 2014;2014:1-8. Article ID 892162.. https://doi.org/1 $0.1155 / 2014 / 892162$

10. Finkelstein JL, Duggan C, Mehta S, Thomas T, Srinivasan K, Kurpad AV. Maternal vitamin d status and adverse pregnancy and neonatal outcomes in India. FASEB J. 2016;30(1):44-6.

11. Mousa A, Abell S, Scragg R, De Courten B. Vitamin D in reproductive health and pregnancy. In Seminars Reprod Med. 2016; 34 (2),. e1-e13). Thieme Medical Publishers.

12. Wei SQ, Qi HP, Luo ZC, Fraser WD. Maternal vitamin D status and adverse pregnancy outcomes: a systematic review and meta-analysis. J Matern Fetal Neonatal Med. 2013;26(9):889-99. https://doi.org/10.3109/14767058.2013. 765849 .

13. Liu N, Kaplan AT, Low J, Nguyen L, Liu GY, Equils O, et al. Vitamin D induces innate antibacterial responses in human trophoblasts via an intracrine pathway. Biol Reprod. 2009;80(3):398-406. https://doi.org/10.1095/ biolreprod.108.073577.

14. Evans KN, Nguyen L, Chan J, Innes BA, Bulmer JN, Kilby MD, et al. Effects of 25-hydroxyvitamin D3 and 1, 25-dihydroxyvitamin D3 on cytokine production by human decidual cells. Biology of reproduction. 2006;75(6): 816-22. https://doi.org/10.1095/biolreprod.106.054056.

15. Nicolaidou P, Hatzistamatiou Z, Papadopoulou A, Kaleyias J, Floropoulou E, Lagona $\mathrm{E}$, et al. Low vitamin $\mathrm{D}$ status in mother-newborn pairs in Greece.
Calcified Tissue International. 2006;78(6):337-42. https://doi.org/10.1007/ s00223-006-0007-5.

16. Dijkstra SH, van BA JJW, de Vleeschouwer $L H$, Huysman WA, van den Akker EL. High prevalence of vitamin D deficiency in newborn infants of high-risk mothers. Arch Dis Child. 2007;92(9):750-3. https://doi.org/10.1136/adc.2006.1 05577.

17. Asaduzzaman M, Basak R, Islam S, Juliana FM, Ferdous T, Islam MJ, et al. Vitamin D deficiency and insufficiency in healthy pregnant women living in Dhaka, Bangladesh. IOSR-JDMS. 2018;17(4):66-73.

18. Zhao Y, Yu Y, Li H, Chang Z, Li Y, Duan Y, et al. Vitamin D status and the prevalence of deficiency in lactating women from eight provinces and municipalities in China. PloS one. 2017;12(3):e0174378. https://doi.org/10.13 71/journal.pone.0174378.

19. Andiran N, Yordam N, Ozon A. Risk factors for vitamin D deficiency in breast-fed newborns and their mothers. Nutrition. 2002;18:47-50. https:// doi.org/10.1016/S0899-9007(01)00724-9.

20. Javaid MK, Crozier SR, Harvey NC, Gale CR, Dennison EM, Boucher BJ, et al. Maternal vitamin D status during pregnancy and childhood bone mass at age 9 years: a longitudinal study. The Lancet. 2006;367(9504):36-43. https:// doi.org/10.1016/50140-6736(06)67922-1.

21. Baggerly CA, Cuomo RE, French CB, Garland CF, Gorham ED, Grant WB, et al. Sunlight and vitamin D: necessary for public health. J Am Coll Nutr. 2015;34(4):359-65. https://doi.org/10.1080/07315724.2015.1039866.

22. Khan KS, Kunz R, Kleijnen J, Antes G. Five steps to conducting a systematic review. Journal of the Royal Society of Medicine. 2003;96(3):118-21. https:// doi.org/10.1177/014107680309600304.

23. Checklist PRISMA statement 2009; Available in http://prisma- statement.org/ PRISMA Statement/Checklist.aspx Accessed December 2018

24. Zhang L, Chow EP, Su S, Yiu WL, Zhang X, lu Kl, et al. A systematic review and meta-analysis of the prevalence, trends, and geographical distribution of HIV among Chinese female sex workers (2000-2011): implications for preventing sexually transmitted HIV. Int J Infect Dis. 2015;39:76-86. https:// doi.org/10.1016/j.ijid.2015.08.014.

25. Hoy D, Brooks P, Woolf A, Blyth F, March L, Bain C, et al. Assessing risk of bias in prevalence studies: modification of an existing tool and evidence of interrater agreement. J Clin Epidemiol. 2012;65(9):934-9. https://doi.org/10.1 016/j.jclinepi.2011.11.014.

26. Assessing risk of bias in included studies - Cochrane Handbook, 2011; Available in http://handbook-51.cochrane.org/chapter_8/8_assessing_risk_ of_bias_in_included_studies.htm. Accessed November 2018.

27. Cochrane Collaboration.RevMan 5.3 user guide. The Cochrane Collaboration. 2014; Available with RevMan, 5.

28. Sergeant, ESG. Epitools epidemiological calculators 2018. Ausvet Pty Ltd. Available at. http://epitools.ausvet.com.au Accessed November 2018.

29. Borenstein $M$, Hedges $L$, Rothstein $H$. Meta-analysis: Fixed effect vs. random effects. Meta-analysis. com. 2007.

30. Ried, K. Interpreting and understanding meta-analysis graphs: a practical guide Reprinted from Australian Family Physician 2006; 35 (8).

31. Sachan A, Gupta R, Das V, Agarwal A, Awasthi PK, Bhatia V. High prevalence of vitamin $D$ deficiency among pregnant women and their newborns in northern India. The American journal of clinical nutrition. 2005;81(5):1060-4. https://doi.org/10.1093/ajcn/81.5.1060.

32. Farrant HJ, Krishnaveni GV, Hill JC, Boucher BJ, Fisher DJ, Noonan K, et al. Vitamin $D$ insufficiency is common in Indian mothers but is not associated with gestational diabetes or variation in newborn size. Eur J Clin Nutr. 2009; 63(5):646-52. https://doi.org/10.1038/ejcn.2008.14.

33. Sahu M, Bhatia V, Agganwal A, Rawat V, Saxena P, Pandey A, et al. Vitamin D deficiency in rural girls and pregnant women despite abundant sunshine in northern India. Clin Endocrinol. 2009;70(5):680-4. https://doi.org/10.1111/j.1365-2265.2008.03360x.

34. Singla R, Dutta U, Aggarwal N, Bhadada SK, Kochhar R, Dhaliwal LK. Vitamin$D$ deficiency is associated with gallbladder stasis among pregnant women. Digestive diseases and sciences. 2015;60(9):2793-9. https://doi.org/10.1007/ s10620-015-3678-9.

35. Ajmani SN, Paul M, Chauhan P, Ajmani AK, Yadav N. Prevalence of vitamin D deficiency in burka-clad pregnant women in a 450-Bedded Maternity Hospital of Delhi. J Obstet Gynecol India. 2016;66(1):67-71. https://doi.org/1 0.1007/s13224-015-0764-z.

36. Sharma S, Kumar A, Prasad S, Sharma S. Current Scenario of Vitamin D Status During Pregnancy in North Indian Population. The Journal of Obstetrics and Gynecology of India. 2016;66(2):93-100. https://doi.org/10.1 007/s13224-014-0658-5. 
37. Krishnaveni GV, Veena SR, Winder NR, Hill JC, Noonan K, Boucher BJ, et al. Maternal vitamin D status during pregnancy and body composition and cardiovascular risk markers in Indian children: the Mysore Parthenon Study. Am J Clin Nutr. 2011;93(3):628-35. https://doi.org/10.3945/ajcn.110.003921.

38. Veena SR, Krishnaveni GV, Srinivasan K, Thajna KP, Hegde BG, Gale CR, et al. Association between maternal vitamin D status during pregnancy and offspring cognitive function during childhood and adolescence. Asia Pacific journal of clinical nutrition. 2017;26(3):438-49. https://doi.org/10.6133/apjcn. 032016.07.

39. Nandal $R$, Chhabra R, Sharma D, Lallar M, Rathee U, Maheshwari $P$. Comparison of cord blood vitamin D levels in newborns of vitamin D supplemented and unsupplemented pregnant women: a prospective, comparative study. J Matern Fetal Neonatal Med. 2016:29(11):1812-6.

40. Kumar P, Shenoi A, Kumar RK, Girish SV, Subbaiah S. Vitamin D Deficiency Among Women in Labor and Cord Blood of Newborns. Indian Pediatr. 2015;52(6):530-1.

41. Chary AV, Hemalatha R, Seshacharyulu M, Murali MV, Jayaprakash D, Kumar $B D$. Vitamin $D$ deficiency in pregnant women impairs regulatory $T$ cell function. J Steroid Biochem Mol Biol. 2015;147:48-55. https://doi.org/10.101 6/j.jsbmb.2014.11.020.

42. Dasgupta A, Saikia UK, Sarma D. Status of $25(\mathrm{OH})$ D levels in pregnancy: A study from the North Eastern part of India. Indian J Endocrinol Metab. 2012; 16(Suppl 2):S405-7. https://doi.org/10.4103/2230-8210.104109.

43. Sablok A, Batra A, Thariani K, Batra A, Bharti R, Aggarwal AR, et al. Supplementation of vitamin $D$ in pregnancy and its correlation with fetomaternal outcome. Clin Endocrinol. 2015;83(4):536-41. https://doi.org/1 $0.1111 /$ cen.12751.

44. Marwaha RK, Tandon N, Chopra S, Agarwal N, Garg MK, Sharma B, et al. Vitamin D status in pregnant Indian women across trimesters and different seasons and its correlation with neonatal serum 25-hydroxyvitamin D levels. Br J Nutr. 2011;106(09):1383-9. https://doi.org/10.1017/S000711451100170X.

45. Higgins JP, Thompson SG, Deeks JJ, Altman DG. Measuring inconsistency in meta-analyses. Bmj. 2003;327(7414):557-60.

46. Junaid K, Rehman A, Jolliffe DA, Wood K, Martineau AR. High prevalence of vitamin $D$ deficiency among women of child-bearing age in Lahore Pakistan, associating with lack of sun exposure and illiteracy. BMC Women's Health. 2015;15(1):83. https://doi.org/10.1186/s12905-015-0242-X.

47. Woo J, Lam CW, Leung J, Lau WY, Lau E, Ling $X$, et al. Very high rates of vitamin $\mathrm{D}$ insufficiency in women of child-bearing age living in Beijing and Hong Kong. Br J Nutr. 2008;99(06):1330-4. https://doi.org/10.1017/S0007114 507844382.

48. Bukhary NBI, Isa ZM, Shamsuddin K, Lin KG, Mahdy ZA, Hassan H, et al. Risk factors for antenatal hypovitaminosis D in an urban district in Malaysia. BMC Pregnancy Childbirth. 2016;16(1):156.

49. Tasset JL. A systematic review of vitamin D deficiency in pregnancy in India and its impact on maternal and fetal outcomes.2014;( Doctoral dissertation, University of Cincinnati).

50. Dovnik A, Mujezinović F, Treiber M, Balon BP, Gorenjak M, Maver U, et al. Seasonal variations of vitamin D concentrations in pregnant women and neonates in Slovenia. Eur J Obstet Gynecol Reprod Biol. 2014;181:6-9. https://doi.org/10.1016/j.ejogrb.2014.07.019.

51. Ono $Y$, Suzuki A, Kotake M, Zhang $X$, Nishiwaki-Yasuda K, Ishiwata $Y$, et al. Seasonal changes of serum 25-hydroxyvitamin D and intact parathyroid hormone levels in a normal Japanese population. J Bone Mineral Metab. 2005:23(2):147-51. https://doi.org/10.1007/s00774-004-0553-8.

52. Mithal A, Wahl DA, Bonjour JP, Burckhardt $P$, Dawson-Hughes B, Eisman JA, et al. Global vitamin D status and determinants of hypovitaminosis D. Osteoporos Int. 2009;20(11):1807-20. https://doi.org/10.1007/s00198-0090954-6.

53. Contreras-Manzano A, Villalpando S, Robledo-Pérez R. Vitamin D status by sociodemographic factors and body mass index in Mexican women at reproductive age. Salud Pública De México. 2017;59:518-25.

54. Pratumvinit B, Wongkrajang $P$, Wataganara T, Hanyongyuth $S$, Nimmannit A, Chatsiricharoenkul $\mathrm{S}$, et al. Maternal vitamin D status and its related factors in pregnant women in Bangkok, Thailand. PloS one. 2015;10(7):e0131126. https://doi.org/10.1371/journal.pone.0131126.

55. Azami MILAD, Shamloo MBB, Nasirkandy MP, Veisani YOUSEF, Rahmati SHOBOO, YektaKooshali MH, et al. Prevalence of vitamin D deficiency among pregnant women in Iran: a systematic review and meta-analysis. Koomesh. 2017:19(3):505-14.
56. Agarwal KS, Mughal MZ, Upadhyay P, Berry JL, Mawer EB, Puliyel JM. The impact of atmospheric pollution on vitamin D status of infants and toddlers in Delhi, India. Arch. Dis. Child. 2002;87(2):111-3. https://doi.org/10.1136/adc. 87.2.111.

57. Van der Meer IM, Karamali NS, Boeke AJ, Lips P, Middelkoop BJ, Verhoeven I, et al. High prevalence of vitamin D deficiency in pregnant non-Western women in The Hague, Netherlands. Am J Clin Nutr. 2006;84(2):350-3. https://doi.org/10.1093/ajcn/84.2.350.

58. Parlak M, Kalay S, Kalay Z, Kirecci A, Guney O, Koklu E. Severe vitamin D deficiency among pregnant women and their newborns in Turkey. The Journal of Maternal-Fetal \& Neonatal Medicine. 2015;28(5):548-51. https:// doi.org/10.3109/14767058.2014.924103.

59. Roth DE, Shah MR, Black RE, Baqui AH. Vitamin D status of infants in northeastern rural Bangladesh: preliminary observations and a review of potential determinants. J Health Popul Nutr. 2010;28(5):458.

60. Kruger MC, Kruger IM, Wentzel-Viljoen E, Kruger A. Urbanization of black South African women may increase risk of low bone mass due to low vitamin D status, low calcium intake, and high bone turnover. Nutr Res. 2011;31(10):748-58. https://doi.org/10.1016/j.nutres.2011.09.012.

61. Misra A, Singhal N, Sivakumar B, Bhagat N, Jaiswal A, Khurana L. Nutrition transition in India: Secular trends in dietary intake and their relationship to diet-related non-communicable diseases. Journal of diabetes. 2011;3(4):27892. https://doi.org/10.1111/j.1753-0407.2011.00139.x.

62. Akhtar S. Vitamin D status in South Asian populations-risks and opportunities. Critical reviews in food science and nutrition. 2016;56(11): 1925-40. https://doi.org/10.1080/10408398.2013.807419.

63. Anwar S, lqbal MP, Azam I, Habib A, Bhutta S, Soofi SB, et al. Urban and rural comparison of vitamin D status in Pakistani pregnant women and neonates. J Obstet Gynaecol. 2016;36(3):318-23.

64. Gupta A. Vitamin D deficiency in India: prevalence, causalities and interventions. Nutrients. 2014;6(2):729-75.

65. Christesen H, Falkenberg T, Lamont R. The impact of vitamin D on pregnancy: a systematic review. Acta Obstetricia et Gynecologica Scandinavica. 2012;91(12):1357-67. https://doi.org/10.1111/aogs.12000.

66. Moghraby SA, Al Shawaf T, Akiel A, Sedrani SH, El Idrissy AT, Al-Meshari AA. Parity and vitamin D metabolites. Ann Trop Paediatr. 1987;7(3):210-3. https://doi.org/10.1080/02724936.1987.11748509.

67. Saraf R, Morton S, Camargo CA, Grant CC. Global summary of maternal and newborn vitamin D status-a systematic review. Matern Child Nutr. 2016; 12(4):647-68. https://doi.org/10.1111/mcn.12210.

68. Shah I, James R, Barker J, Petroczi A, Naughton DP. Misleading measures in Vitamin D analysis: a novel LC-MS/MS assay to account for epimers and isobars. Nutrition Journal. 2011;10(1):46. https://doi.org/10.1186/1475-2891-1 $0-46$.

69. Recommended dietary Allowance for Indians. 2010; available in ninindia. org/ dietaryguidelinesforninwebsite.pdf Accessed February 2019.

70. WHA65, R. 11. Nutrition. Maternal, infant and young child nutrition: draft comprehensive implementation plan. Sixth-fifth World Health Assembly, Geneva, 2012; 21-26. (http://apps.who.int/gb/ebwha/pdf_files/WHA65/A 65_11-en.pdf, accessed 18 December 2018).

71. Holick MF. Vitamin D deficiency. New England Journal of Medicine. 2007; 357(3):266-81. https://doi.org/10.1056/NEJMra070553.

72. Bandeira F, Griz L, Dreyer P, Eufrazino C, Bandeira C, Freese E. Vitamin D deficiency: a global perspective. Arquivos Brasileiros de Endocrinologia \& Metabologia. 2006;50(4):640-6. https://doi.org/10.1590/S0004-273020060004 00009 .

73. Micka AE. Vitamin D status among Bangladeshi women of reproductive age, 2009; (Doctoral dissertation, University of Massachusetts Amherst).

74. Eyles D, Anderson C, Ko P, Jones A, Thomas A, Burne T, et al. A sensitive LC/ MS/MS assay of $250 \mathrm{H}$ vitamin D 3 and $250 \mathrm{H}$ vitamin D 2 in dried blood spots. Clinica Chimica Acta. 2009;403(1):145-51. https://doi.org/10.1016/j. cca.2009.02.005

\section{Publisher's Note}

Springer Nature remains neutral with regard to jurisdictional claims in published maps and institutional affiliations. 